\title{
TEMPERAMENTUM- ÉS KARAKTERTÍPUSOK ÖSSZEFÜGGÉSE A SZUBKLINIKUS DEPRESSZIÓS TÜNETEGYÜTTESSEL, DISZFUNKCIONÁLIS ATTITÚDÖKKEL ÉS MEGKÜZDÉSI STRATÉGIÁKKAL
}

\author{
MARGITICS FERENC ${ }^{1 *}$ - PAUWLIK ZSUZSA ${ }^{1}$ - \\ PETRIKA ERZSÉBET ${ }^{2}$ \\ ${ }^{1}$ Nyíregyházi Főiskola, Pszichológia Tanszék, Nyíregyháza \\ ${ }^{2}$ Nyíregyházi Fớiskola, Testnevelés és Sporttudományi Tanszék, Nyíregyháza \\ (Beérkezett: 2005. július 10.; elfogadva: 2005. október 3.)
}

\begin{abstract}
Célkitûzés: jelen tanulmány célja a Cloninger-féle Temperamentum és Karakter Kérdôívvel (TCI) elkülöníthetô egyes temperamentum- és karaktertípusoknak a depressziós tünetekkel, diszfunkcionális attitủdökkel és megküzdési stratégiákkal való kapcsolatának vizsgálata, fóiskolai hallgatók körében. Módszer: a vizsgálatban részt vevő főiskolai hallgatók (n = 681) közül 465 nó, 216 férfi volt. A temperamentum- és karaktertípusok elkülönítésére a TCI-t, a depresszió mérésére a Beck-féle Depresszió Kérdóív rövidített változatát használtuk. A diszfunkcionális attitúdöket a Weismann-féle Diszfunkcionális Attitûd Skála magyar változatával, a megküzdési stratégiákat a Folkman és Lazarus-féle Konfliktusmegoldó Kérdőív magyar adaptációjával mértük. Eredmények: vizsgálataink azt mutatják, hogy minden temperamentum- és karaktertípus jellemezhető volt a depressziós tünetek, diszfunkcionális attitúdök és megküzdési stratégiák egyedi kombinációjával. Vizsgálataink során feltártuk az érett és éretlen karaktertípusokra jellemezô diszfunkcionális attitúdöket és megküzdési stratégiákat is. Konklúzió: vizsgálatunk eredményei az egyetemista, főiskolai hallgatók egyre növekvő táborának mentális egészségével foglalkozó szakemberek munkájához nyújthat segítséget, következtetéseink elsősorban a tanácsadási gyakorlatban használhatók fel eredményesen.
\end{abstract}

Kulcsszavak: temperamentum- és karaktertípusok, érett és éretlen karakter, depressziós tünetegyüttes, diszfunkcionális attitúdök, megküzdési stratégiák

\footnotetext{
* Levelező szerző: Margitics Ferenc, 4400 Nyíregyháza, Déri Miksa u. 23.

E-mail: margif@zeus.nyf.hu
} 


\section{BEVEZETÉS}

Az utóbbi két évtizedben a személyiség alapvetô típusainak meghatározásához - egymástól függetlenül - két eltéró úton is eljutottak a kutatók. Az egyik a faktoranalitikus út, amely a „Big Five” személyiségmodell kialakításához vezetett. A másik a neurobiológiai út, amely az egyéni különbségek hátterét alkotó neurobiológiai bázist tárta fel, és a „Big Three” személyiségmodellt alakította ki. Az évek során több empirikus kutatás is megerősítette mindkét modell érvényességét.

A nyolcvanas évek végén alakította ki Cloninger (1987) neurobiológiai személyiségmodelljét, amelyben a két modell integrációjára tett kísérletet. Tanulmányunkban nem térünk ki részletesen a cloningeri elméletre, mivel azt Osváth (2003), valamint Rózsa és mtsai (2005) tanulmányaikban részletesen ismertetik.

Cloninger (1987) integratív személyiségmodelljében a temperamentum kialakulásában az öröklött tényezóknek, a karakter kialakulásánál a tanulásnak, a környezeti hatásoknak tulajdonít nagyobb szerepet. Szerinte a temperamentum és a karakter együtt határozza meg az egész személyiséget. A különbözó temperamentum- és karakterdimenziók kapcsolatának figyelembevételével különféle temperamentum- és karaktertípusokat különített el.

A cloningeri elmélet egyes temperamentumskálákra (újdonságkeresés, ártalomkerülés és jutalomfüggóség) adott pontszámok magas vagy alacsony értéke alapján nyolc temperamentumtípust különböztet meg. Ezek és jellemzóik a következók (Rózsa és mtsai 2005):

- Az antiszociális temperamentumra a veszélykeresés, dacos szembenállás, nonkonformizmus, ridegség jellemzó.

- A hisztrionikus temperamentum szenvedélyes, hiszékeny, figyelemfelkeltó, fantáziagazdag.

- A passzív-agresszív temperamentumnál bizonytalanság, követelódzés és manipulatív hajlam figyelhetô meg.

- A borderline temperamentumra hangulati bizonytalanság, gyenge teljesítóképesség, döntésképtelenség jellemzó.

- Az obszesszív-kompulzív temperamentum módszeres, tárgyilagos, szenvtelen, ennek ellenére alacsony az önérvényesítése.

- A szkizoid temperamentumra függetlenség, makacsság, túlzott magabiztosság, függetlenség és magánykeresés jellemzó.

- A ciklotím temperamentumot meggyôzố rámenôsség, túlzott magabiztosság, természetes nyíltság jellemzi.

- A passzív-dependens temperamentum óvatos, önalárendeló, tiszteletteljes, aggályoskodó. 
Cloninger elméletében a következó karaktertípusokat különítette el, és a következóképpen jellemezte óket (Rózsa és mtsai 2005):

- Az ingerlékeny (dependens) karakter szubmisszív, bizakodó, másokkal tiszteletteljes, sértésre és kritikára érzékeny, ingerlékeny.

- A melankolikus (lehangolt) karakter kevés pozitív érzelmet él át, érzéseit többnyire a szenvedés, szégyen és gyúlölet jellemzi.

- Az autoriter karakter ésszerú, önzó, erôszakos, célorientált, versengó, ellenséges, valamint a keménykezú irányítás jellemzi.

- A rendezett karakter konzervatív, konzisztens, figyel a részletekre és törvényekre, büszke logikus gondolkodására, a hatalom és javak elónybe részesítése jellemzi.

- A ciklotímiás (szeszélyes) karakter szuggesztibilis, elutasításra érzékeny, bizonytalan, gyakori hangulati ingadozás és a múlékony örömök előnyben részesítése jellemzó rá.

- A szkizotipikus (rendezetlen) karakter dezorientált, ragaszkodik a magányához, viselkedését nem képes realisztikus célokra irányítani, élénk és excentrikus lehet.

- A paranoid (fanatikus) karaktert alacsony együttmúködési készség jellemzi, gyanakvó, kitartó, célorientált.

- A kreatív (felvilágosult) karakter gyakran él át pozitív érzelmeket, érett, leleményes, elmélkedô, szabadszellemú.

Cloninger (1987) szerint míg a temperamentumkonstellációkból a személy prediszpozícióira tudunk következtetni, addig a karakterkonstellációk alakulását befolyásolja a szocializáció, a szociokulturális tanulás, így ezekból a személyiség érettségét határozhatjuk meg.

A temperamentumtípusok határozzák meg a különböző személyiségzavarokra való hajlamot. A hajlam megjelenése azonban a karakterdimenzióktól függ. Az éretlen karakterrel jellemezhetó személyeknél a temperamentumtípusának megfelelő személyiségzavar kialakulásának kockázata igen nagy. Cloninger integratív személyiségmodelljében a személyiségzavarok a temperamentum szélsôséges megnyilvánulásainak tekinthetốk (Osváth 2003; Rózsa és mtsai 2005).

Jelen tanulmány célja, hogy az elmúlt években kidolgozott és világszerte egyre szélesebb körben alkalmazott, hazánkban Rózsa és mtsai (2005) által adaptált Cloninger-féle Temperamentum és Karakter Kérdôívvel (TCI) elkülöníthetố temperamentum- és karaktertípusok egyes jellemzóit részletesebben vizsgáljuk. Elsősorban az egyes temperamentum- és karaktertípusoknak a depressziós tünetekkel, diszfunkcionális attitúdökkel és megküzdési stratégiákkal való kapcsolatát szeretnénk részletesebben feltárni, fóiskolai hallgatók körében. Szeretnénk megvizsgálni az egyes 
temperamentumtípusok összefüggéseit az érett és éretlen karaktertípussal is. Vizsgálatunk eredményeivel szeretnénk hozzájárulni az egyetemista, fóiskolai hallgatók egyre növekvő táborának mentális egészségével foglalkozó szakemberek munkájának segítéséhez.

\section{MÓDSZEREK}

\section{Vizsgálati személyek}

Az adatgyújtés a Nyíregyházi Fóiskola hallgatói körében történt, minden karon, véletlenszerúen kiválasztott hallgatók körében. A részvétel minden esetben önkéntes alapon, a hallgató beleegyezésével történt. Az önkitöltéses kérdốiveket előadás keretében, a kutatók irányításával vettük fel.

A vizsgálatban 700 főiskolai hallgató vett részt, közülük 681 fónek volt értékelhetô a kitöltött kérdőíve (465 nô, 216 férfi).

A szakok szerinti megoszlás a következóképpen alakult: 225 fó humán szakos tanár, 125 reál szakos tanár, 125 gazdasági szakos, 74 tanító szakos hallgató, 70 szociálpedagógus és 62 múvészeti tanár szakos hallgató.

Az életkor átlaga 19,98 (szórás 1,51), a medián értéke 20 év volt.

Az egyes temperamentum- és karaktertípusok vizsgálatakor a vizsgálati csoportba került az éppen vizsgált temperamentum- vagy karaktertípus, a kontrollcsoportba a minta fennmaradó része (pl. az antiszociális temperamentumtípus vizsgálatakor a vizsgálati csoportba 50 fő, a kontrollcsoportba 631 fó került).

\section{Vizsgálati eszközök}

A kutatások során a következő vizsgálati eszközöket használtuk:

Aktuális depressziós tünetek vizsgálata: Beck-féle Depresszió Skála rövidített, 13 tételes, szứró változata (Beck és Beck 1972; Szádóczky 2001; Margitics 2005). A Beck-féle Depresszió Skála rövidített, 13 tételes, szúró változata és a kérdőívben elért pontszámok határértékei magyar nyelven a Szádóczky Erika által lektorált (a háziorvosi és pszichiátriai gyakorlatban alkalmazott) „Depresszió, szorongás pontozó skálák” címú kiadványban (Szádóczky 2001), valamint Margitics (2005) tanulmányában hozzáférhetô.

Attitüdök vizsgálata: Weismann-féle Diszfunkcionális Attitúd Skála (DAS) magyar változata (Kopp 1994). A kérdőív a következő attitúdöket 
vizsgálja: külsô elismerés igénye, szeretettség igénye, teljesítményigény, perfekcionizmus, jogos, a környezet felé irányuló fokozott elvárások, omnipotencia (fokozott altruista beállítottság), külsó kontroll-autonómia.

Megküzdési stratégiák vizsgálata: A Folkman és Lazarus-féle Konfliktusmegoldó Kérdőív magyar adaptációja (Kopp 1994). A következó konfliktuskezelési stratégiák különíthetók el a kérdốivvel: problémaelemzés, kognitív átstrukturálás, alkalmazkodás, érzelmi indíttatású cselekvés, érzelmi egyensúly keresése, visszahúzódás, segítségkérés.

A temperamentum és karakter vizsgálata: a Cloninger-féle Temperamentum és Karakter Kérdôív (TCI) Rózsa és mtsai által adaptált magyar változata (Rózsa és mtsai 2005). A kérdőív 4 temperamentum és 3 karakter dimenziót mérô skálát alkot. Ezek a következók:

- temperamentumskálák: újdonságkeresés, ártalomkerülés, jutalomfüggóség, kitartás;

- karakterskálák: önirányítottság, együttmúködés, transzcendencia.

\section{Statisztikai elemzés}

A leíró statisztika mellett a vizsgálati és kontrollcsoport összehasonlító statisztikai vizsgálatához kétmintás t-próbát alkalmaztunk. Az adatok feldolgozása SPSS for Windows 12.0 statisztikai programcsomag felhasználásával történt.

\section{EREDMÉNYEK}

\section{A temperamentum- és karaktertípusok eloszlása}

Cloninger a temperamentum- és karaktertípusok kialakításánál a TCI egyes skáláin elért pontszámok mediánjait, Rózsa és mtsai pedig a skálákon kapott pontszámok transzformációjával létrehozott 50-es T-értéket vették alapul (Rózsa és mtsai 2005).

Mi a temperamentum- és karaktertípusok markánsabb megjelenítése és elkülönítése szándékától vezérelve eltértünk ettól a különválasztási módtól. Nálunk a hangsúly az egyes skálákon elért eredmények kvartiliseire került. Alacsony értéknek számított az a pontszám, amely az adott skála első kvartilisébe, magasnak pedig az, amelyik a negyedik kvartilisbe esett (1. táblázat). 
1. táblázat. A Temperamentum és Karakter Kérdôív kvartilisei

\begin{tabular}{|l|c|c|c|c|c|}
\hline \multirow{2}{*}{$\begin{array}{l}\text { A Temperamentum } \\
\text { és Karakter Kérdóív } \\
\text { skálái }\end{array}$} & \multirow{2}{*}{ Medián } & \multicolumn{4}{|c|}{ Kvartilisek } \\
\cline { 3 - 6 } & & elsó & második & harmadik & negyedik \\
\hline Újdonságkeresés & 22 & $0-18$ & $19-22$ & $23-26,5$ & $27-40$ \\
\hline Ártalomkerülés & 17 & $0-12$ & $13-17$ & $18-22$ & $23-35$ \\
\hline Jutalomfüggóség & 18 & $0-15$ & $16-18$ & $19-20$ & $21-24$ \\
\hline Kitartás & 4 & $0-2$ & $3-4$ & $5-6$ & $7-8$ \\
\hline Önirányítottság & 28 & $0-24$ & $25-28$ & $29-33,5$ & $34-44$ \\
\hline Együttmúködés & 30 & $0-25$ & $26-30$ & $31-35$ & $36-42$ \\
\hline Transzcendencia & 17 & $0-13$ & $14-17$ & $18-21$ & $22-33$ \\
\hline
\end{tabular}

A 2. táblázat mutatja be a temperamentumtípusok cloningeri osztályozását (Rózsa és mtsai 2005), valamint azok eloszlását a mintán belül.

2. táblázat. A temperamentumtípusok osztályozásának szempontjai és eloszlása a mintában

\begin{tabular}{|l|c|c|c|c|c|c|c|}
\hline $\begin{array}{l}\text { Temperamentum- } \\
\text { típusok }\end{array}$ & $\begin{array}{c}\text { Újonság- } \\
\text { keresés }\end{array}$ & $\begin{array}{c}\text { Ártalom- } \\
\text { kerülés }\end{array}$ & $\begin{array}{c}\text { Jutalom- } \\
\text { függóség }\end{array}$ & $\begin{array}{c}\text { Eset- } \\
\text { szám }\end{array}$ & $\%$ & Nó & férfi \\
\hline Antiszociális & magas & alacsony & alacsony & 50 & 7,3 & 25 & 25 \\
\hline Hisztrionikus & magas & alacsony & magas & 48 & 7 & 32 & 16 \\
\hline Passzív-agresszív & magas & magas & magas & 27 & 4 & 23 & 4 \\
\hline Borderline & magas & magas & alacsony & 23 & 3,4 & 14 & 9 \\
\hline $\begin{array}{l}\text { Obszesszív- } \\
\text { kompulzív }\end{array}$ & alacsony & magas & alacsony & 51 & 7,5 & 30 & 21 \\
\hline $\begin{array}{l}\text { Szkizoid } \\
\text { Ciklotím }\end{array}$ & alacsony & alacsony & alacsony & 27 & 4 & 10 & 17 \\
\hline Passzív-dependens & alacsony & magacsony & magas & 33 & 4,8 & 27 & 6 \\
\hline
\end{tabular}

A fenti szempontokat figyelembe véve 312 személyt (210 nó, 102 férfi) tudtunk az egyes temperamentumtípusokba besorolni.

Rózsa és mtsai (2005) normatív mintán 8-15\% között találták az egyes temperamentumtípusok előfordulási arányát. Nálunk, a vizsgált mintánál ez az érték 3,4-7,8\% között mozgott. Az eltérés az általunk használt szigorúbb besorolási módból fakadhat. A legnagyobb előfordulási arányt a passzív-dependens $(7,8 \%)$, obszesszív-kompulzív (7,5\%) és antiszociális $(7,3 \%)$ temperamentumnál találtuk. A legalacsonyabb előfordulási 
arányt borderline (3,3\%), passzív-agresszív (4\%) és szkizoid temperamentum (4\%) esetében találtuk. Ezek az eredmények - a szkizoid kivételével - megegyeznek Rózsa és mtsai normatív mintán elért eredményeivel.

A 3. táblázat mutatja be a karaktertípusok cloningeri osztályozását (Rózsa és mtsai 2005), valamint eloszlását a mintán belül.

3. táblázat. A karaktertípusok osztályozásának szempontjai és eloszlása a mintában

\begin{tabular}{|l|c|c|c|c|c|c|c|}
\hline $\begin{array}{l}\text { Temperamentum- } \\
\text { típusok }\end{array}$ & $\begin{array}{c}\text { Önirányí- } \\
\text { tottság }\end{array}$ & $\begin{array}{c}\text { Együttmú- } \\
\text { ködés }\end{array}$ & $\begin{array}{c}\text { Transzcen- } \\
\text { dencia }\end{array}$ & $\begin{array}{c}\text { Eset- } \\
\text { szám }\end{array}$ & $\%$ & Nő & Férfi \\
\hline Ingerlékeny & alacsony & magas & alacsony & 24 & 3,5 & 21 & 3 \\
\hline Melankolikus & alacsony & alacsony & alacsony & 79 & 11,6 & 51 & 28 \\
\hline Autoriter & magas & alacsony & alacsony & 27 & 4 & 16 & 11 \\
\hline Rendezett & magas & magas & alacsony & 63 & 9,2 & 44 & 19 \\
\hline Ciklotímiás & alacsony & magas & magas & 44 & 6,5 & 29 & 15 \\
\hline Szkizotípiás & alacsony & alacsony & magas & 48 & 7 & 26 & 22 \\
\hline Paranoid & magas & alacsony & magas & 16 & 2,3 & 12 & 4 \\
\hline Kreatív & magas & magas & magas & 61 & 9 & 51 & 10 \\
\hline
\end{tabular}

A fenti szempontokat figyelembe véve 362 személyt (250 nó, 112 férfi) tudtunk az egyes karaktertípusokba besorolni.

A különbözó karaktertípusok elófordulási aránya 2,3-11,6\% között mozgott. A legmagasabb elófordulási arányt a melankolikus (11,6\%), rendezett $(9,2 \%)$ és kreatív $(9 \%)$, a legalacsonyabbat a paranoid $(2,3 \%)$, ingerlékeny $(3,5 \%)$ és autoriter (4\%) típus mutatta.

\section{Az érett és éretlen karaktertípusok eloszlása}

Cloninger az alacsony önirányítottsággal és együttmúködési készséggel rendelkezố személyeket tekintette éretlennek, akiknél a különbözố személyiségzavarok megjelenési kockázata nagy. Cloniger, valamint Rózsa és mtsai is az érett és éretlen karakter elkülönítésére a fenti skálák mediánjainak az összegét használták (Rózsa és mtsai 2005).

Mi eltértünk a fenti számítási módtól, mert ez azokat a személyeket is éretlen karakternek tekintette, akik csak az egyik skálán értek el alacsonyabb pontszámot, de ennek ellenére a két skálaösszeg alatta maradt a mediánokból képzett összegnek. Mi csak azokat a vizsgálati személyeket tekintettük éretlen karakterúnek, akik mindkét skálán alacsony pontszámot értek el. Ennek kiszámításához nem a mediánokat vettük alapul, 
hanem a kvartiliseket. Éretlen karakternél a két skála elsô kvartilise felsó határértékének az összegénél húztuk meg a határt (49 pont), s az ettól alacsonyabb pontszámot elért személyeket soroltuk ebbe a kategóriába. Érett karakternek a negyedik kvartilis alsó határának összegénél (70 pont) magasabb pontszámot elért személyeket tekintettük.

A fentieknek megfelelóen 212 személyt (165 nő, 47 férfi) soroltunk az éretlen karakterek, 217 fót (126 nő, 91 férfi) az érettek közzé.

Rózsa és mtsai (2005) a már említett számítási módszerrel normatív mintán 29\%-nak találták az éretlen karakterek előfordulási arányát. Nálunk az éretlen karakterek elófordulása 31,1\% volt. Ez az arány férfiaknál 21,5\%, nóknél 35,5\%. Ha figyelembe vesszük az általunk használt szigorúbb számítási módot, akkor az éretlen karaktereknek az előfordulási aránya nagyon magasnak túnik fóiskolai hallgatók körében.

A 4. táblázat mutatja be, hogyan alakult a különbözó temperamentumtípusok száma a karakterek érettsége szerint.

A következókben az érett és éretlen karakterek arányát a különbözó temperamentumtípusoknak a mintán belüli elófordulási arányához viszonyítva mutatjuk be. A temperamentumtípusok mögött zárójelben megadjuk az adott temperamentumtípussal elóforduló és beazonosítható karakterek elnevezését is.

Az éretlen karakterek legmagasabb elófordulási arányát, 69,5\%-ot a borderline temperamentumnál találtuk (melankolikus 8 fó, szkizotípiás 4 fó, ciklotímiás 1 fố), majd 51\%-kal az obszesszív-kompulzív (melankolikus 8 fó, szkizotípikus 3 fó, ingerlékeny 2 fó, rendezett 1 fó) követke-

4. táblázat. A különbözô temperamentumtípusok számának alakulása a karakterek érettsége szerint (a \%-os arány a temperamentumtípusoknak a mintán belüli előfordulásához való viszonyát adja meg)

\begin{tabular}{|l|c|c|c|c|}
\hline \multirow{2}{*}{$\begin{array}{l}\text { Temperamentum- } \\
\text { típusok }\end{array}$} & \multicolumn{2}{|c|}{ Éretlen karakterek } & \multicolumn{2}{c|}{ Érett karakterek } \\
\cline { 2 - 5 } & száma & $\%$ & száma & $\%$ \\
\hline Antiszociális & 18 & 36 & 15 & 30 \\
\hline Hisztrionikus & 6 & 12,5 & 24 & 50 \\
\hline Passzív-agresszív & 12 & 44 & 4 & 15 \\
\hline Borderline & 16 & 69,5 & 1 & 4 \\
\hline Obszesszív-kompulzív & 26 & 51 & 4 & 8 \\
\hline Szkizoid & 7 & 26 & 14 & 52 \\
\hline Ciklotím & 1 & 3 & 27 & 82 \\
\hline Passzív-dependens & 11 & 21 & 19 & 36 \\
\hline
\end{tabular}


zett, melyet a passzív-agresszív 44\%-kal (szkizotipikus 5 fó, melankolikus 2 fó, ciklotím 1 fó), végül az antiszociális 36\%-kal (melankolikus 8 fó, ingerlékeny 1 fó, szkizotipikus 1 fő, rendezett 1 fó) követett.

Az éretlen karakterek aránya a ciklotímia temperamentumtípus esetében volt a legalacsonyabb, 3\% (szkizotípiás 1 fó). Alacsony volt még az éretlen karakterek elófordulási aránya a hisztrionikus temperamentumtípusnál 12,5\%-kal (melankolikus 2 fó, szkizotípikus 1 fố), valamint a passzív-dependens temperamentumtípusnál 21\%-kal (melankolikus 4 fó, ciklotím 2 fó) és a szkizoid temperamentumtípusnál 26\%-kal (melakolikus 2 fó, szkizotípikus 1 fó, paranoid 1 fó).

A legtöbb érett karaktert, 82\%-ot a ciklotímia temperamentumtípus esetében találtunk (kreatív 10 fó, rendezett 9 fó, autoriter 1 fó, ciklotímiás 1 fó), majd a szkizoid temperamentumtípus következett 52\%-kal (rendezett 8 fó, kreatív 3 fố). Ốket a hisztrionikus temperamentumtípus követte 50\%-kal (kreatív 11 fó, ciklotímiás 3 fó, rendezett 2 fó), végül a passzív dependens temperamentumtípus következett, 36\%-kal (melankolikus 4 fó, ciklotímiás 2 fó). Az érett karakterek aránya a borderline temperamentumtípusnál volt a legalacsonyabb (4\%). Alacsony volt még az érett karakterek elófordulási aránya, $8 \%$ az obszesszív-kompulzív (rendezett 1 fó), 15\% a passzív-agresszív (kreatív 1 fó) és 30\% az antiszociális (kreatív 3 fó, rendezett 3 fó, autoriter 2 fó) temperamentumtípusok esetében.

\section{A depressziós tünetegyüttes vizsgálata}

A temperamentumtípusoknál a legmagasabb depressziószintet a passzívagresszív $(\mathrm{M}=8,6, \mathrm{SD}=3,9)$, az obszesszív-kompulzív $(\mathrm{M}=8,1, \mathrm{SD}=$ $4,8)$, a borderline $(M=8,1, S D=3,6)$ és a passzív-dependens $(M=7,4$, $\mathrm{SD}=3,9)$ típusokra találtuk jellemzónek. Alacsonynak találtuk a depressziószintet a ciklotímia $(\mathrm{M}=2,8, \mathrm{SD}=3,4)$, az antiszociális $(\mathrm{M}=4,2$, $\mathrm{SD}=3)$, a szkizoid $(M=4,9, \mathrm{SD}=3)$ és a hisztrionikus $(M=5, S D=3,7)$ típusok esetében.

A karaktertípusokat vizsgálva szubklinikus depressziós tünetegyüttest leginkább a ciklotim $(\mathrm{M}=9,6, \mathrm{SD}=5)$, a melankolikus $(\mathrm{M}=8,5, \mathrm{SD}=$ $5,3)$, a szkizotipikus $(M=7,9, S D=4,3)$ és az ingerlékeny $(M=7,6, S D=$ $4,5)$ karakterekre találtuk jellemzónek. Alacsonynak találtuk a depressziós szintet a rendezett $(\mathrm{M}=3,3, \mathrm{SD}=2,6)$, kreatív $(\mathrm{M}=3,5, \mathrm{SD}=2,8)$, autoriter $(\mathrm{M}=4,3, \mathrm{SD}=3,3)$ és a paranoid $(\mathrm{M}=4,7, \mathrm{SD}=2,5)$ karakterek esetében.

Megvizsgáltuk azt is, hogy az egyes temperamentum- és karaktertípusok milyen összefüggést mutatnak az egyes, a Beck-féle Depresszió Skálával mérhetô depressziós tünetekkel (5. táblázat). 
5. táblázat. A temperamentum- és karaktertípusok összefüggése az egyes depressziós tünetekkel

\begin{tabular}{|c|c|c|c|c|c|c|c|c|c|c|c|c|c|}
\hline \multirow{2}{*}{$\begin{array}{l}\text { A BDI-vel mérhetó } \\
\text { depressziós } \\
\text { tünetek }\end{array}$} & \multicolumn{13}{|c|}{ Szignifikanciaszint $(\mathrm{p}<)$} \\
\hline & 1 & 2 & 3 & 4 & 5 & 6 & 7 & 8 & 9 & 10 & 11 & 12 & 13 \\
\hline \multicolumn{14}{|l|}{ Temperamentum } \\
\hline Antiszociális & $0,007^{*}$ & $0,013^{*}$ & n.s. & $0,028^{*}$ & n.s. & n.s. & n.s. & n.s. & $0,048^{*}$ & n.s. & n.s. & n.s. & n.s. \\
\hline Hisztrionikus & n.s. & $0,005^{*}$ & n.s. & n.s. & n.s. & n.s. & n.s. & n.s. & n.s. & n.s. & n.s. & n.s. & n.s. \\
\hline Passzív-agresszív & n.s. & 0,001 & n.s. & n.s. & n.s. & 0,009 & 0,021 & n.s. & n.s. & n.s. & n.s. & 0,004 & n.s. \\
\hline Borderline & n.s. & n.s. & 0,001 & n.s. & 0,005 & n.s. & n.s. & n.s. & n.s. & n.s. & 0,012 & n.s. & n.s. \\
\hline Obszesszív-kompluzív & 0,001 & 0,001 & 0,001 & 0,038 & 0,001 & n.s. & n.s. & n.s. & 0,033 & n.s. & n.s. & n.s. & 0,035 \\
\hline Szkizoid & n.s. & n.s. & n.s. & n.s. & n.s. & n.s. & n.s. & n.s. & n.s. & $0,011^{*}$ & $0,008^{*}$ & n.s. & n.s. \\
\hline Ciklotím & $0,024^{*}$ & n.s. & $0,044^{*}$ & $0,001^{*}$ & $0,001^{*}$ & $0,008^{*}$ & n.s. & n.s. & $0,001^{*}$ & & $0,009^{*}$ & $0,004^{*}$ & n.s. \\
\hline Passzív-dependens & n.s. & 0,001 & 0,046 & n.s. & n.s. & n.s. & n.s. & n.s. & n.s. & 0,008 & n.s. & n.s. & n.s. \\
\hline \multicolumn{14}{|l|}{ Karakter } \\
\hline Ingerlékeny & n.s. & 0,029 & n.s. & n.s. & n.s. & n.s. & n.s. & n.s. & n.s. & 0,027 & n.s. & n.s. & n.s. \\
\hline Melankolikus & 0,001 & 0,001 & 0,001 & 0,001 & 0,001 & 0,006 & & 0,001 & 0,019 & & 0,001 & 0,012 & 0,030 \\
\hline Autoriter & n.s. & $0,004^{*}$ & n.s. & n.s. & n.s. & n.s. & n.s. & n.s. & n.s. & n.s. & $0,031^{*}$ & $0,047^{*}$ & n.s. \\
\hline Rendezett & $0,001^{*}$ & $0,002^{*}$ & $0,001^{*}$ & $0,005^{*}$ & $0,002^{*}$ & $0,048^{*}$ & $0,014^{*}$ & $0,015^{*}$ & $0,007^{*}$ & $0,019^{*}$ & $0,001^{*}$ & $0,036^{*}$ & n.s. \\
\hline Ciklotímiás & 0,001 & 0,006 & 0,007 & n.s. & 0,001 & 0,003 & n.s. & n.s. & 0,001 & 0,001 & 0,049 & 0,004 & 0,039 \\
\hline Szkizotípiás & n.s. & 0,035 & 0,012 & n.s. & 0,028 & n.s. & 0,018 & n.s. & 0,045 & 0,004 & 0,037 & 0,048 & n.s. \\
\hline Paranoid & n.s. & n.s. & n.s. & n.s. & n.s. & n.s. & n.s. & n.s. & n.s. & n.s. & n.s. & n.s. & n.s. \\
\hline Kreatív & $0,003^{*}$ & $0,032^{*}$ & $0,001^{*}$ & $0,005^{*}$ & $0,001^{*}$ & $0,040^{*}$ & $0,002^{*}$ & $0,021^{*}$ & $0,001^{*}$ & $0,013^{*}$ & n.s. & n.s. & n.s. \\
\hline
\end{tabular}

1 = szomorúság, 2 = reménytelenség, $3=$ kudarcok, $4=$ elégedetlenség, $5=$ értéktelenség, $6=$ önbüntetés, $7=$ szuicid gondolatok, $8=$ érdektelenség, 9 = döntésképtelenség, 10 = testképzavar, 11 = munkaképtelenség, 12 = fáradtság, 13 = étvágytalanság, n.s. = nem szignifikáns, * = negatív irányú kapcsolat 
A minta egészéhez $(n=681)$ viszonyítva az egyes temperamentumtípusokra a következó depressziós tüneteket találtuk jellemezónek:

- Az antiszociális temperamentum szignifikánsan eltért a minta többi részétól szomorúság, reménytelenség, elégedetlenség és döntésképtelenség hiánya tekintetében.

- A hisztrionikus temperamentumra csak a reménytelenség alacsony szintjét találtuk jellemzőnek.

- A passzív-agresszív temperamentumnál a reménytelenséget, az önbüntetést, a szuicid gondolatokat és a fáradtságot tudtuk kimutatni.

- A borderline temperamentumra a kudarcokat, értéktelenséget és munkaképtelenséget találtuk jellemzőnek.

- Az obszesszív-kompulzív temperamentumnál a szomorúságot, reménytelenséget, elégedetlenséget, kudarcokat, értéktelenség érzését, döntésképtelenséget és étvágytalanságot tudtunk kimutatni.

- A szkizoid temperamentumra a testképzavar hiányát és a jó munkavégző-képességet találtuk jellemzónek.

- A ciklotím temperamentumot a szomorúság, elégedetlenség, kudarcok, értéktelenség érzés, önbüntetés hiánya, valamint a jó döntési és munkavégzố képesség jellemezte.

- A passzív-dependens temperamentumnál reménytelenséget, kudarcokat és testképzavart tudtuk kimutatni.

Az egyes karaktertípusokra a következó depressziós tüneteket találtuk jellemezónek:

- Az ingerlékeny karakterre a reménytelenség és testképzavar volt jellemzô.

- A melankolikus karakternél a szomorúságot, reménytelenséget, elégedetlenséget, kudarcokat, értéktelenség érzését, önbüntetést, érdektelenséget, döntésképtelenséget, fáradtságot, munkaképtelenséget és étvágytalanságot találtunk jellemzónek.

- Az autoriter karakterre a reménytelenség hiányát és a jó munkavégzó képességet találtuk jellemzónek.

- A rendezett karakterre találtuk a legkevésbé jellemzónek a depressziós tüneteket, az étvágytalanság kivételével minden tünet szignifikánsan kevésbé jellemezte óket, mint a minta többi részét.

- A ciklotímiás karakterre a szomorúságot, reménytelenséget, kudarcokat, értéktelenség érzését, önbüntetésre való hajlamot, döntésképtelenséget, testképzavart, munkaképtelenséget, fáradtságot és étvágytalanságot találtuk jellemzónek.

- A szkizotipikus karakternél reménytelenséget, kudarcokat, értéktelen- 
ség érzését, szuicid gondolatokat, döntésképtelenséget, testképzavart, munkaképtelenséget és fáradtságot tudtunk kimutatni.

- A paranoid karakter egyik depressziós tünettel sem mutatott szignifikáns kapcsolatot.

- A kreatí karakterre szintén nem találtuk jellemzónek a depressziós tüneteket, a munkaképtelenség, fáradtság és étvágytalanság kivételével minden tünet szignifikánsan kevésbé jellemezte óket, mint a minta többi részét.

Az érett és éretlen karaktereknek a Beck-féle Depresszió Skálán elért eredményeinek a leíró statisztikája a következóképpen alakult, a minta egészére nézve:

- éretlen karakter $(n=212, M=7,4, S D=4,6)$; érett karakter $(n=217$, $\mathrm{M}=4, \mathrm{SD}=3$ ).

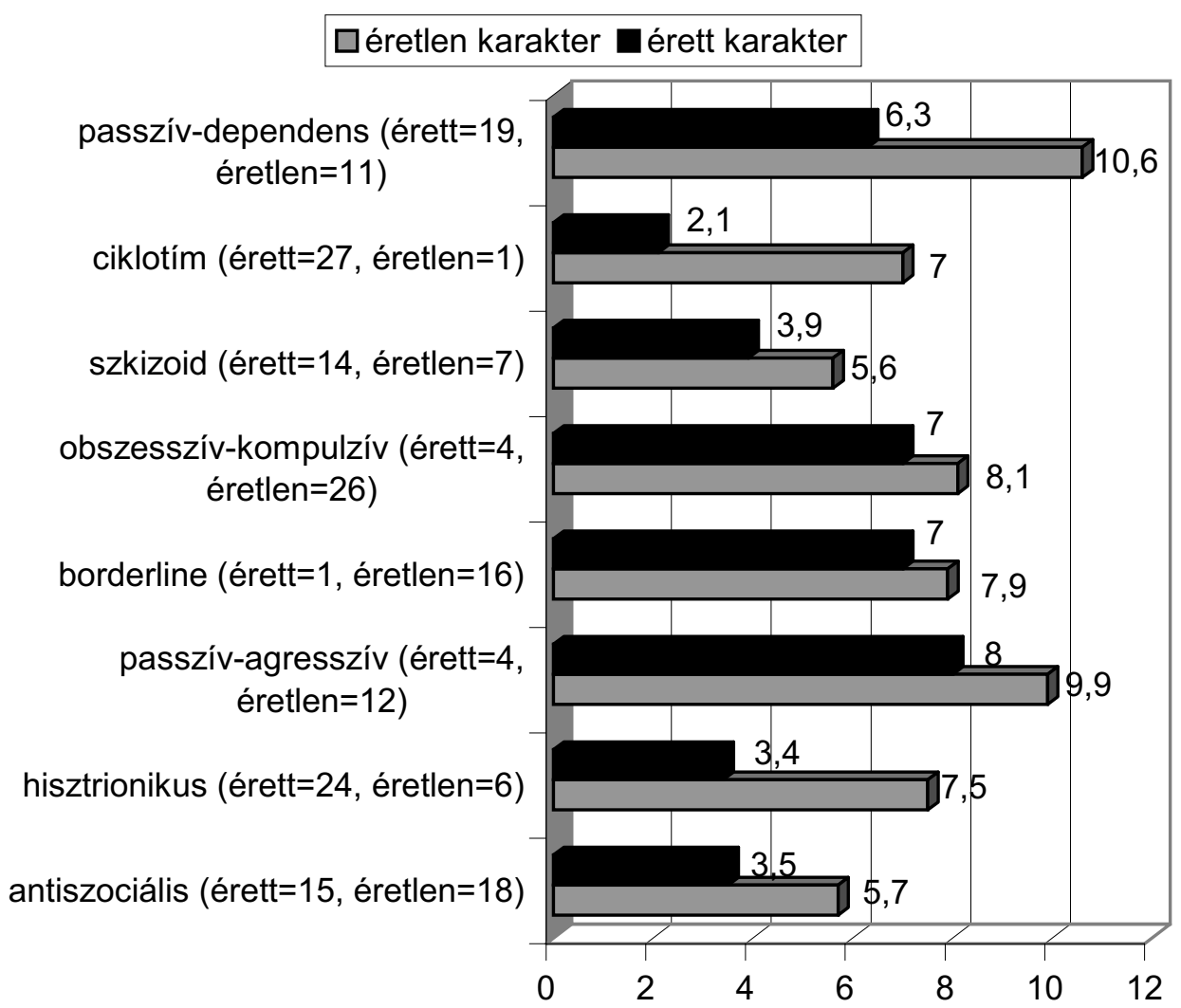

1. ábra. A temperamentumtípusok Beck-féle Depresszió Skálán elért átlagainak alakulása a karakterek érettsége szerint 
Nemenként vizsgálva ugyanezt a következóképpen alakultak az eredmények:

- férfiak: éretlen karakter ( $\mathrm{n}=47, \mathrm{M}=6,1, \mathrm{SD}=4,2)$; érett karakter $(\mathrm{n}=91, \mathrm{M}=3,2, \mathrm{SD}=2,2)$;

- nók: éretlen karakter $(\mathrm{n}=165, \mathrm{M}=8,4, \mathrm{SD}=4,6)$; érett karakter $(\mathrm{n}=126, \mathrm{M}=4,2, \mathrm{SD}=3,2)$.

Az érett és éretlen karaktereket összehasonlítva a szubklinikus depressziós tünetegyüttes tekintetében jelentôs eltérést találtunk a két karaktertípus között $(t=9,597, p<0,001)$. Az éretlen karakterre szignifikánsan jobban jellemzónek találtuk a depressziós tünetegyüttest.

Az 1. ábráról kitúnik, hogy ha a különbözó temperamentumtípusokat a karakterek érettsége szempontjából vizsgáljuk, akkor az éretlen karakterek minden esetben magasabb pontot értek el a Beck-féle Depresszió Skálán.

A passzív-agresszív, obszesszív-kompulzív és a passzív-dependens temperamentumtípusok esetében nemcsak az éretlen, hanem az érettnek minősített karakterek is emelkedett depresszió-pontszámot értek el a Beckféle Depresszió Skálán. A hisztrionikus és ciklotím temperamentumtípusok esetében viszont míg az éretlen karakterek emelkedett, addig az érett karakterek alacsony pontszámot értek el. Az antiszociális és szkizoid temperamentumtípusok esetében az érett karakterek alacsony pontszáma mellett az éretlenek pontszáma sem mutatott jelentôsebb emelkedést.

\section{Diszfunkcionális attitúdök vizsgálata}

A 6. táblázatban találjuk meg azt, hogy az egyes temperamentum- és karaktertípusok milyen összefüggést mutattak a Diszfunkcionális Attitúd Skála egyes skáláival.

A minta egészéhez $(n=681)$ viszonyítva az egyes temperamentumtípusokra a következó attitúd-konstellációkat találtuk jellemezónek:

- Az antiszociális temperamentumra alacsony külsó elismerésigény, szeretetigény és teljesítményigény volt jellemzó.

- A hisztrionikus temperamentumra csak az alacsony perfekcionizmust találtuk jellemzónek.

- A passzív-agresszív temperamentumra a fokozott külsó kontrollosság és szeretetigény volt jellemző.

- A borderline temperamentumra csak a fokozott külsó kontrollosságot találtuk jellemzőnek.

- Az obszesszív-kompulzív temperamentumra csak a magas teljesítményigény, valamint fokozott külsố kontrollosság volt jellemzó. 
6. táblázat. A különböző temperamentum- és karaktertípusok kapcsolata a Diszfunkcionális Attitúd Skála egyes skáláival.

\begin{tabular}{|c|c|c|c|c|c|c|c|}
\hline \multirow[b]{2}{*}{ A DAS skálái \ } & \multicolumn{7}{|c|}{ Szignifikanciaszint $(\mathrm{p}<)$} \\
\hline & 1 & 2 & 3 & 4 & 5 & 6 & 7 \\
\hline \multicolumn{8}{|l|}{ Temperamentum } \\
\hline Antiszociális & $0,001^{*}$ & $0,013^{*}$ & $0,029 *$ & n.s. & n.s. & n.s. & n.s. \\
\hline Hisztrionikus & n.s. & n.s. & n.s. & $0,021^{*}$ & n.s. & n.s. & n.s. \\
\hline Passzív-agresszív & n.s. & 0,034 & n.s. & n.s. & n.s. & n.s. & 0,010 \\
\hline Borderline & n.s. & n.s. & n.s. & n.s. & n.s. & n.s. & 0,017 \\
\hline Obszesszív-kompluzív & n.s. & n.s. & 0,002 & n.s. & n.s. & n.s. & 0,033 \\
\hline Szkizoid & n.s. & n.s. & n.s. & n.s. & $0,001^{*}$ & n.s. & n.s. \\
\hline Ciklotím & n.s. & n.s. & n.s. & n.s. & n.s. & n.s. & $0,001^{*}$ \\
\hline Passzív-dependens & n.s. & 0,035 & n.s. & n.s. & n.s. & n.s. & 0,007 \\
\hline \multicolumn{8}{|l|}{ Karakter } \\
\hline Ingerlékeny & n.s. & n.s. & n.s. & n.s. & n.s. & n.s. & n.s. \\
\hline Melankolikus & n.s. & n.s. & n.s. & 0,036 & n.s. & n.s. & 0,033 \\
\hline Autoriter & n.s. & n.s. & n.s. & n.s. & n.s. & n.s. & n.s. \\
\hline Rendezett & $0,009^{*}$ & $0,017^{*}$ & $0,020 *$ & $0,002^{*}$ & n.s. & n.s. & $0,001^{*}$ \\
\hline Ciklotímiás & n.s. & n.s. & n.s. & n.s. & n.s. & n.s. & n.s. \\
\hline Szkizotípiás & 0,001 & n.s. & 0,003 & n.s. & n.s. & n.s. & 0,001 \\
\hline Paranoid & n.s. & n.s. & n.s. & n.s. & n.s. & 0,033 & n.s. \\
\hline Kreatív & n.s. & n.s. & n.s. & $0,029^{*}$ & n.s. & n.s. & $0,021^{*}$ \\
\hline
\end{tabular}

1 = külsó elismerés igénye, 2 = szeretetigény, 3 = teljesítményigény, 4 = perfekcionizmus, 5 = környezet felé irányuló elvárások, $6=$ altruizmus, $7=$ külsó-kontroll, n.s. = nem szignifikáns, * = negatív irányú kapcsolat

- A szkizoid temperamentumra a környezet felé irányuló elvárások alacsonyabb szintje volt jellemző.

- A ciklotím temperamentumot elsősorban az autonómiára való törekvés jellemezte.

- A passzív-dependens temperamentumra a külsó kontrollosságot és fokozott szeretetigényt találtuk jellemzónek.

Az egyes karaktertípusokra a következő attitúd-konstellációkat találtuk jellemezónek:

- Az ingerlékeny karakterre nem találtunk jellemzó attitúdöt.

- A melankolikus karakterre a perfekcionizmus és külső kontrollosság volt jellemző.

- Az autoriter karakterre szintén nem találtunk jellemzó attitúdöt.

- A rendezett karakternek kisebb a külsó elismerés utáni vágya, a teljesítmény- és a szeretetigénye. Ezeken kívül fokozott az autonómiára való törekvés. 
- A ciklotímiás karakterre nem találtunk jellemzó attitúdöt

- A szkizotipikus karakternél a magasabb külsó elismerés- és teljesítményigényt, valamint a fokozott külső kontrollosságot találtuk jellemzónek.

- A paranoid karakter csak a fokozott altruizmus területén tért el szignifikáns mértékben a minta egészétól.

- A kreatí karakterre kevésbé találtuk jellemzőnek a perfekcionizmust, valamint fokozott autonómiára való törekvés mutatkozott náluk.

Megvizsgáltuk azt is, hogy az érett és éretlen karakterek milyen összefüggést mutatnak az egyes diszfunkcionális attitúdökkel.

A 2. ábra mutatja be az egyes karaktertípusoknak a Diszfunkcionális Attitúd Skálán elért átlagait.

A két karaktertípus között a következő attitúdöknél tudtunk szignifikáns eltérést kimutatni:

- külsó elismerés igénye $(\mathrm{t}=4,133, \mathrm{p}<0,001)$,

- szeretetigény $(t=2,137, p<0,033)$,

éretlen karakter $(n=212)$ 口érett karakter $(n=217)$ Degész minta $(n=618)$

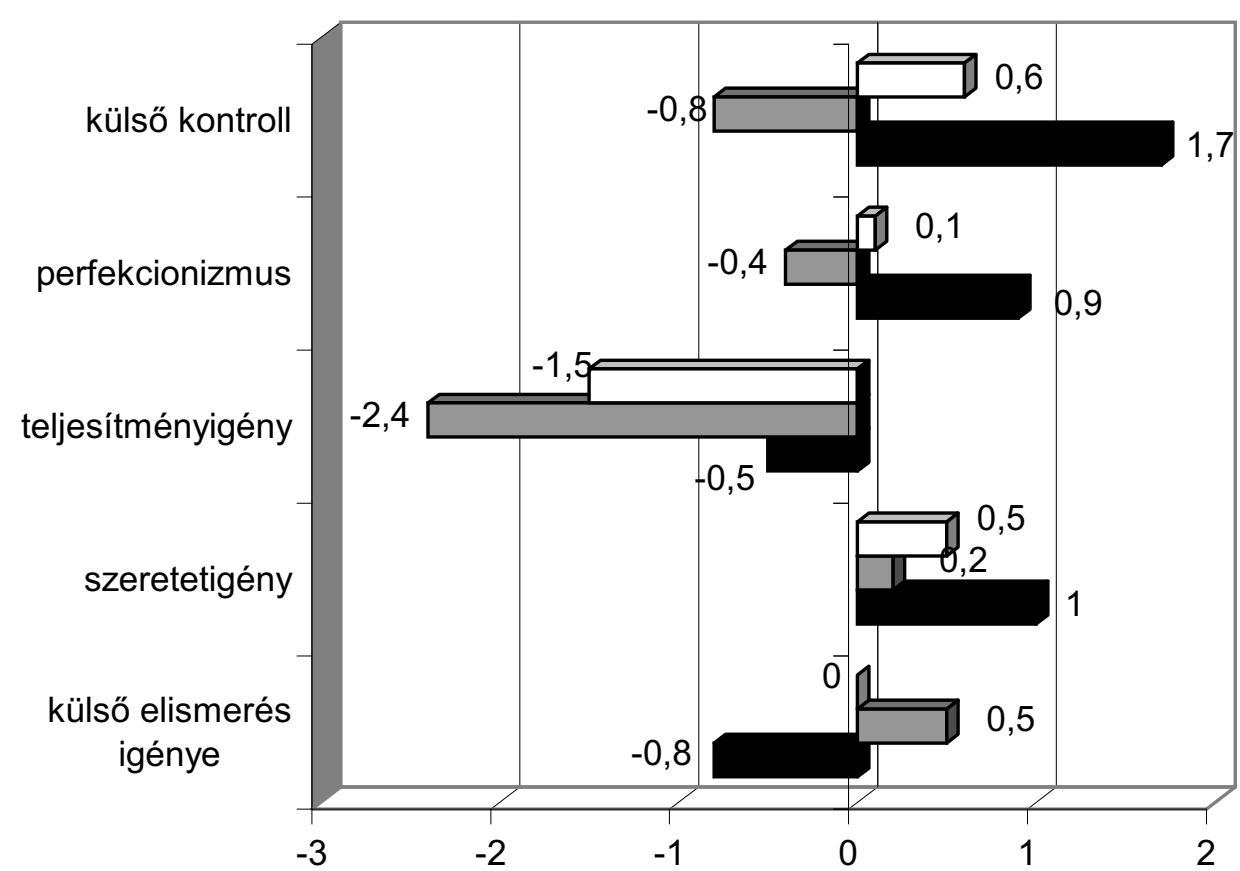

2. ábra. Az egyes karaktertípusoknak a Diszfunkcionális Attitúd Skálán elért átlagai 
- teljesítményigény $(t=4,684, p<0,001)$,

- perfekcionizmus $(t=4,076, p<0,001)$,

- külsố kontroll ( $\mathrm{t}=7,408, \mathrm{p}<0,001)$.

Az éretlen karaktert a külsó kontrollosság, szeretetigény, alacsony teljesítményigény mellett megjelenô perfekcionizmus, valamint a külsô elismerés igényének alacsonyabb szintje jellemezte.

Az érett karakterre az autonómiára való törekvés, alacsony teljesítményigény és perfekcionizmus, alacsonyabb szeretetigény és kicsit magasabb külsó elismerésigény volt jellemzô (a minta egészéhez viszonyítva is).

A nemeket külön vizsgálva a nóknél szintén ki tudtuk mutatni a fenti szignifikáns eltéréseket a két karaktertípus között. Náluk még egy területen találtunk jelentôsebb eltérést, ez a környezet felé irányuló elvárások $(t=2,186, p<0,03)$. Ez jobban jellemzó volt az éretlen karakterú nókre.

A férfiaknál a szeretetigény kivételével szintén jelentkeztek a fenti jelentôs eltérések az érett és éretlen karakterek között. Ezen a területen nem találtunk különbséget a két karaktertípus között.

\section{Megküzdési stratégiák vizsgálata}

A 7. táblázatban találjuk meg azt, hogy az egyes temperamentum- és karaktertípusok milyen összefüggést mutattak a Konfliktusmegoldó Kérdôív egyes skáláival.

A minta egészéhez viszonyítva $(n=681)$ az egyes temperamentumtípusokra a következó megküzdési módokat találtuk jellemezőnek:

- Az antiszociális temperamentumra azt találtuk jellemzónek, hogy szignifikánsan kevésbé hajlamos a visszahúzódásra és segítségkérésre.

- A hisztrionikus temperamentumnál az érzelemközpontú stratégiák közül az érzelmi egyensúly keresésére való fokozottabb törekvést tudtunk kimutatni. A problémaközpontú stratégiák esetében a kognitív átstrukturálás és alkalmazkodás elónyben részesítését tártuk fel náluk. A segítségkérés megküzdési módként való alkalmazása szintén jellemzó volt erre a temperamentumtípusra.

- A passzív-agresszív temperamentumra az érzelemközpontú stratégiák közül az érzelmi indíttatású cselekvést találtuk jellemzónek. Ezen kívül a segítségkérés magasabb szintjét tudtuk kimutatni náluk.

- A borderline temperamentumnál a problémaközpontú stratégiák közül a problémaelemzés alacsony szintjét mutattuk ki. Az érzelmi központú megküzdési stratégiák közül az érzelmi indíttatású cselekvés elônyben részesítését, valamint az érzelmi egyensúly keresésére való 
7. táblázat. A különböző temperamentum- és karaktertípusok kapcsolata a Konfliktusmegoldó Kérdőív egyes skáláival

\begin{tabular}{|c|c|c|c|c|c|c|c|}
\hline \multirow{2}{*}{$\begin{array}{l}\text { A Konfliktusmegoldó } \\
\text { Kérdóív skálái }\end{array}$} & \multicolumn{7}{|c|}{ Szignifikanciaszint $(\mathrm{p}<)$} \\
\hline & 1 & 2 & 3 & 4 & 5 & 6 & 7 \\
\hline \multicolumn{8}{|l|}{ Temperamentum } \\
\hline Antiszociális & n.s. & n.s. & n.s. & n.s. & $0,037^{*}$ & n.s. & $0,001^{*}$ \\
\hline Hisztrionikus & n.s. & 0,026 & 0,034 & n.s. & n.s. & 0,002 & 0,006 \\
\hline Passzív-agresszív & n.s. & n.s. & n.s. & 0,044 & n.s. & n.s. & 0,016 \\
\hline Borderline & $0,001^{*}$ & n.s. & n.s. & 0,014 & n.s. & 0,007 & $0,050^{*}$ \\
\hline Obszesszív-kompulzív & n.s. & n.s. & n.s. & n.s. & 0,034 & n.s. & n.s. \\
\hline Szkizoid & n.s. & n.s. & n.s. & $0,003^{*}$ & n.s. & n.s. & n.s. \\
\hline Ciklotím & n.s. & 0,004 & n.s. & $0,004^{*}$ & n.s. & n.s. & 0,008 \\
\hline Passzív-dependens & n.s. & n.s. & $0,045^{*}$ & n.s. & n.s. & $0,003^{*}$ & 0,024 \\
\hline \multicolumn{8}{|l|}{ Karakter } \\
\hline Ingerlékeny & n.s. & $0,004^{*}$ & n.s. & n.s. & n.s. & $0,034^{*}$ & n.s. \\
\hline Melankolikus & $0,001^{*}$ & $0,001^{*}$ & n.s. & n.s. & n.s. & n.s. & $0,005^{*}$ \\
\hline Autoriter & n.s. & n.s. & $0,050^{*}$ & n.s. & $0,016^{*}$ & n.s. & $0,017^{*}$ \\
\hline Rendezett & 0,002 & n.s. & n.s. & $0,001^{*}$ & $0,028^{*}$ & $0,001^{*}$ & n.s. \\
\hline Ciklotímiás & n.s. & n.s. & 0,009 & n.s. & 0,001 & n.s. & 0,001 \\
\hline Szkizotípiás & $0,027^{*}$ & n.s. & n.s. & 0,001 & 0,025 & 0,004 & n.s. \\
\hline Paranoid & n.s. & n.s. & n.s. & n.s. & 0,033 & n.s. & n.s. \\
\hline Kreatív & n.s. & 0,005 & n.s. & $0,014^{*}$ & n.s. & n.s. & 0,001 \\
\hline
\end{tabular}

1 = problémaelemzés, 2 = kognitív átstrukturálás, 3 = alkalmazkodás, 4 = érzelmi indíttatású cselekvés, 5 = visszahúzódás, 6 = érzelmi egyensúly keresése, 7 = segítségkérés, n.s. = nem szignifikáns, * = negatív irányú kapcsolat

törekvést találtuk jellemzőnek. Nehéz élethelyzetekben viszont kevésbé hajlandók segítséget kérni a környezetüktól.

- Az obszesszív-kompulzív temperamentumra a problémaközpontú stratégiáknál nem találtunk jellemzô megküzdési módot, az érzelemközpontúaknál is csak a visszahúzódásra való fokozott hajlamot tudtuk kimutatni.

- A szkizoid temperamentumra a problémaközpontú stratégiák közül szintén nem találtunk jellemzőt. Az érzelemközpontú stratégiák közül az érzelmi indíttatású cselekvés alacsonyabb mértékét találtuk jellemzónek rájuk.

- A ciklotím temperamentumra a problémaközpontú megküzdés területén a kognitív átstrukturálás előnyben részesítését találtuk jellemzốnek. Érzelemközpontú stratégiáknál csak az érzelmi indíttatású cselekvés alacsony szintjét tudtuk kimutatni náluk. Valamint azt találtuk, hogy segítségkérésre is hajlamosabbak, mint a minta egésze. 
- A passzív-dependens temperamentumra az alkalmazkodás és érzelmi egyensúly keresésére való törekvés alacsonyabb, és a segítségkérésre való hajlam magasabb szintjét találtuk jellemzónek.

Az egyes karaktertípusokra a következô megküzdési módokat találtuk jellemezőnek:

- Az ingerlékeny karakterre problémaközpontú megküzdés területén a kognitív átstrukturálás, az érzelemközpontú stratégiák közül az érzelmi egyensúly keresés alacsonyabb szintjét találtuk jellemzónek.

- A melankolikus karakternél a problémaelemzés és kognitív átstrukturálás, valamint a segítségkérés alacsonyabb szintjét tudtuk kimutatni.

- Az autoriter karakterre az alkalmazkodás és visszahúzódás, valamint segítségkérés hiányát találtuk jellemzónek.

- A rendezett karakterre problémaközpontú megküzdés területén a problémaelemzésre való hajlamot találtuk jellemzőnek. Az érzelem-

éretlen karakter $(n=212) \square$ érett karakter $(n=217) \square$ egész minta $(n=618)$

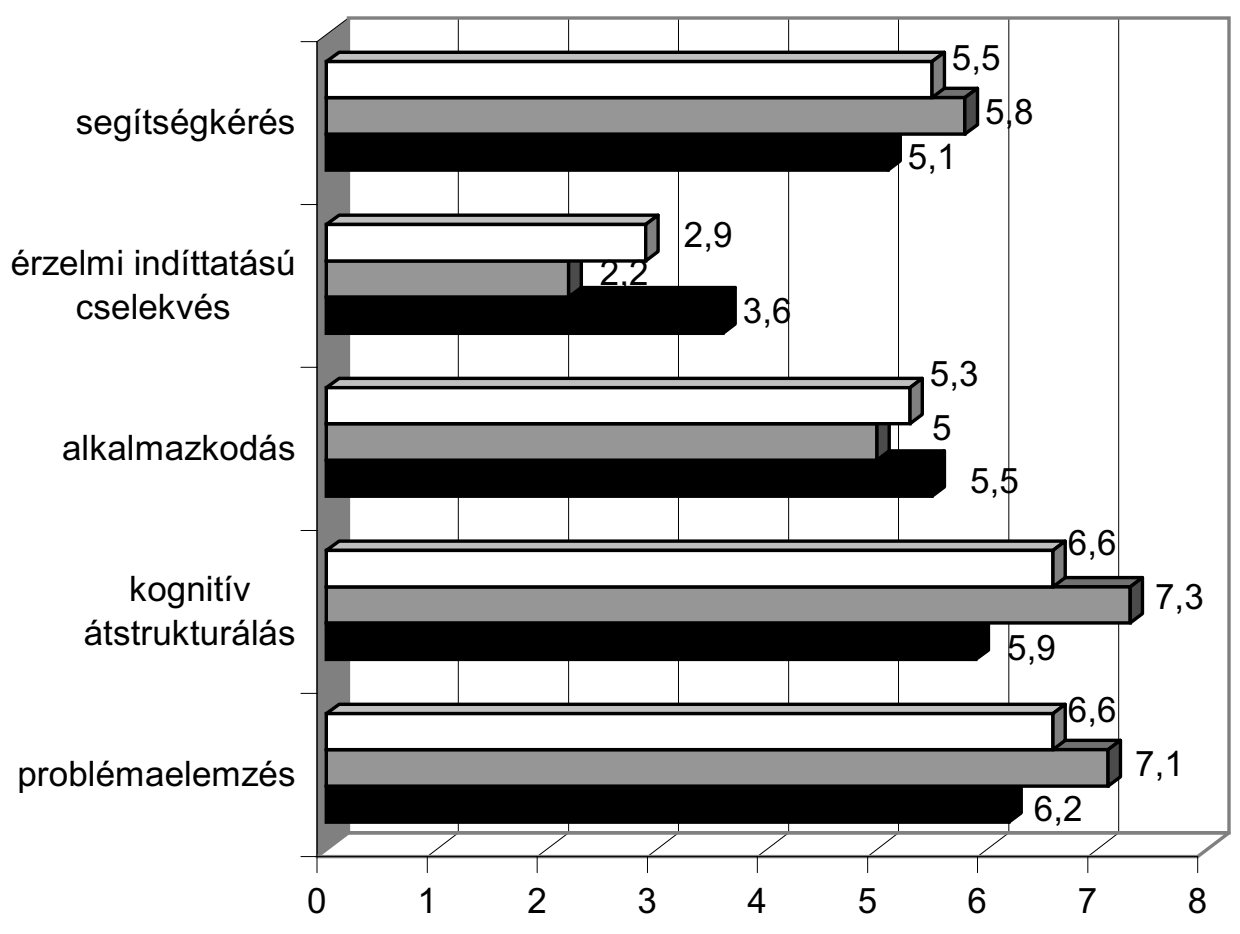

3. ábra. Az egyes karaktertípusoknak

a Konfliktusmegoldó Kérdőív egyes skáláin elért átlagai 
központú stratégiáknál az érzelmi indíttatású cselekvés, a visszahúzódás és érzelmi egyensúly keresésére való törekvés alacsonyabb szintjét tudtuk kimutatni.

- A ciklotímiás karakterre az alkalmazkodás, a visszahúzódás és a segítségkérés magasabb szintjét találtuk jellemzónek.

- A szkizotipikus karakternél a problémaközpontú megküzdés területén a problémaelemzésre való hajlam alacsonyabb szintjét találtuk jellemzőnek. Az érzelemközpontú stratégiáknál az érzelmi indíttatású cselekvés, a visszahúzódás és érzelmi egyensúly keresésére való törekvés magasabb szintjét tudtuk kimutatni.

- A paranoid karakterre csak a visszahúzódás elónyben részesítését találtuk jellemzónek.

- A kreatív karakternél a kognitív átstrukturálás elónyben részesítését, az érzelmi indíttatású cselekvés alacsony szintjét, valamint a segítségkérésre való hajlamot tudtuk kimutatni.

Megnéztük azt is, hogy az érett és éretlen karakterek milyen összefüggést mutatnak az egyes megküzdési stratégiákkal.

A 3. ábra mutatja be az egyes karaktertípusoknak a Konfliktusmegoldó Kérdő́iv egyes skáláin elért átlagait.

A két karaktertípus között a következô megküzdési módok területén tudtunk szignifikáns eltérést kimutatni:

- problémaelemzés $(t=5,605, p<0,001)$,

- kognitív átstrukturálás $(\mathrm{t}=6,209, \mathrm{p}<0,001)$,

- alkalmazkodás $(t=2,303, p<0,022)$,

- érzelmi indíttatású cselekvés $(t=7,168, p<0,001)$,

- segítségkérés $(t=3,732, p<0,001)$.

Az éretlen karakter is használja a problémaközpontú megküzdési módokat, de kevésbé, mint az érett karakter. Nehéz élethelyzetekben hajlamosabb az érzelmi indíttatású cselekvésre, valamint kevésbé kér segítséget a környezetétól, mint az érett karakter.

A nemeket külön vizsgálva a nóknél az alkalmazkodás kivételével szintén ki tudtuk mutatni a fenti szignifikáns eltéréseket a karaktertípusok között. A nők esetében az éretlen karakterre szignifikánsan jobban jellemzó volt még az érzelmi egyensúly keresése, mint az érett karakterre $(t=2,243, p<0,026)$.

A férfiaknál az alkalmazkodás és segítségkérés kivételével szintén ki tudtuk mutatni a fenti szignifikáns eltéréseket a két karaktertípus között. Ezen felül még azt találtuk, hogy az érzelmi egyensúly keresése $(\mathrm{t}=2,979$, $\mathrm{p}<0,004)$ és a visszahúzódás $(\mathrm{t}=2,102, \mathrm{p}<0,039)$ szignifikánsan jobban jellemezte az éretlen karakterú férfiakat. 


\section{MEGBESZÉLÉS}

Vizsgálataink alapján az egyes temperamentumtípusokról a következőket tudtuk megállapítani:

Az antiszociális temperamentum kevésbé függ a környezetétól, kevésbé igényli annak külső elismerését és szeretetét. Teljesítményigénye alacsony. Nehéz élethelyzetekben nem kér segítséget a környezetétól, és kevésbé hajlamos a visszahúzódásra.

A hisztrionikus temperamentumra nem jellemzó a perfekcionizmus. Problémamegoldását a kognitív átstrukturálás és alkalmazkodás jellemzi. Nehéz élethelyzetekben képes környezetétól segítséget kérni, és törekszik érzelmi egyensúlyának visszaállítására. Nem jellemző rá a reménytelenség.

A passzív-agresszív temperamentum külsố kontrollos, környezete felé fokozott a szeretetigénye. Könnyen reménytelenné válik, ami önbüntetésre való törekvéssel és szuicid gondolatok megjelenésével járhat együtt. Fáradékony. Nehéz élethelyzetekben érzelmi indíttatású cselekvésre hajlamos, valamint környezetétól kér segítséget problémái megoldásához.

A borderline temperamentum értéktelennek, kudarcokkal terheltnek érzi magát, amiért - külsó kontrollosságából kifolyólag - a környezetét teszi felelőssé. Nehéz élethelyzetekben nem jellemző rá a problémák elemzése, inkább érzelmi indíttatású cselekedetek, vagy érzelmi egyensúly keresésére való törekvés jellemzik. A munkaképtelenség érzése szintén jellemző lehet rá.

Az obszesszív-kompulzív temperamentum magas teljesítményigénye külső kontrollossággal párosul. Ez és a döntésképtelensége azonban megnehezítheti a számára elvárható teljesítmény elérését, ami a kudarcérzéssel társulva elégedetlenség, reménytelenség, szomorúság és értéktelenség érzését állandósíthatja nála. Nehéz élethelyzetekben visszahúzódásra hajlamos. Jellemzó lehet rá az étvágytalanság.

A szkizoid temperamentum teherbírása, munkaképessége jó, elfogadja önmagát. A környezete felé kevesebb elvárással fordul, érzelmeit kontrollálja, nehéz élethelyzetekben nem jellemzố rá az érzelmi indíttatású cselekvés.

A ciklotím temperamentum a vizsgálatunk eredményei szerint fokozottan törekszik az autonómiára, problémáit kognitív átstrukturálással oldja meg. Nehéz élethelyzetekben a környezetétól kér segítséget, érzelmeit kontrollálja, nem jellemzô rá az érzelmi indíttatású cselekvés. Általában vidám, elégedett, határozott, magas önértékelésú személy, aki energikus és teherbíró.

A passzív-dependens temperamentum külsó kontrollos, fokozott szeretetigénnyel fordul a környezete felé. Könnyen válik reménytelenné, ku- 
darcokra érzékeny és önelfogadása alacsony szintú. Nehéz élethelyzetekben a környezetéhez fordul segítségért, de kevésbé törekszik az alkalmazkodásra és érzelmi egyensúly keresésére. Külsó kontrollosságából fakadóan problémái megoldását elsósorban a környezetétól várja el.

Az egyes karakterípusokra a következóket találtuk jellemezónek:

Az ingerlékeny karakterre nehéz élethelyzetekben nem jellemzó a kognitív átstrukturálás használata és az érzelmi egyensúly keresése. Könnyen reménytelenné válik, és önelfogadása alacsony szintú.

A melankolikus karakterre a perfekcionizmus jellemző. A kognitív átstrukturálásra való képesség hiánya, a döntésképtelensége, valamint a külsó kontrollosság ellenére a környezetból származó segítségkérés hiánya meghiúsítja perfekcionista törekvéseit, ami kudarcélmény, szomorúság, reménytelenség, elégedetlenség, értéktelenségérzés, önbüntetésre való hajlam, érdektelenség, fáradtság, munkaképtelenség és étvágytalanság kialakulásához vezethet.

Az autoriter karakter nehéz élethelyzetekben nem alkalmazkodik környezetéhez, nem kér segítséget tóle, nem hajlamos a visszahúzódásra. Bizakodó, energikus, munkaképes.

A rendezett karakter nem vár külsó elismerést és szeretetet a környezetétól, fokozott autonómiára való törekvés jellemzi. Teljesítményigénye fokozott. Nehéz élethelyzetekben nem hajlamos az érzelmi indíttatású cselekvésre, sem visszahúzódásra, sem érzelmi egyensúly keresésére, hanem szembenéz a problémáival és hajlamos a problémaelemzésre. Érzelmileg kiegyensúlyozott, önértékelése magas, energikus, terhelhetô.

A ciklotímiás karakterre a szomorúságot, reménytelenséget, kudarcokat, értéktelenség érzését, önbüntetésre való hajlamot, döntésképtelenséget, testképzavart, munkaképtelenséget, fáradtságot és étvágytalanságot találtuk jellemzónek. Nehéz élethelyzetben képes segítséget kérni a környezetétól, megpróbál alkalmazkodni, vagy visszahúzódik.

A szkizotipikus karakternek magas a külsó elismerés- és teljesítményigénye, ami külsó kontrollossággal párosul. Döntésképtelensége és a problémaelemzố hajlandóság hiánya azonban megnehezíti teljesítményigényének a teljesülését. Érzékeny a kudarcra, ami a reménytelenség, értéktelenség érzését, szuicid gondolatokat okozhat nála. Önmagával elégedetlen, nem terhelhetó, fáradékony. Nehéz élethelyzetekben hajlamos az érzelmi indíttatású cselekvésre, érzelmi egyensúly keresésére vagy a visszahúzódásra.

A paranoid karaktert fokozott altruista attitúd jellemzi. Nehéz élethelyzetekben hajlamos a visszahúzódásra. Egyik depressziós tünettel sem mutatott szignifikáns kapcsolatot

A kreatív karakterre a fokozott autonómiára való törekvést találtuk jel- 
lemzónek. Nem jellemzố rá a perfekcionizmus. Nehéz élethelyzetekben segítséget kér a környezetétól, nem hajlamos érzelmi indíttatású cselekedetekre, érzelmi egyensúly keresésére, vagy visszahúzódásra, inkább kognitív átstrukturálással oldja meg problémáit. Érzelmileg kiegyensúlyozott, önértékelése magas

A karakterek érettségét nézve, vizsgálataink alapján az egyes karaktertípusokra a következóket találtuk jellemezőnek:

Az éretlen karaktert a külsó kontrollosság, szeretetigény, alacsony teljesítményigény mellett megjelenó perfekcionizmus, valamint a külsó elismerés igény alacsonyabb szintje jellemezte. Nehéz élethelyzetekben kevésbé használja a problémaközpontú megküzdési módokat (problémaelemzés, kognitív átstrukturálás, alkalmazkodás), hajlamosabb az érzelmi indíttatású cselekvésre, valamint kevésbé kér segítséget a környezetétól, mint az érett karakter. Az éretlen karakterre szignifikánsan jobban jellemzónek találtuk a depressziós tünetegyüttest.

Az érett karakterre autonómiára való törekvés, alacsony teljesítményigény, perfekcionizmus, alacsonyabb szeretetigény és kicsit magasabb külsó elismerésigény volt jellemzó. Nehéz élethelyzetekben inkább a problémaközpontú megküzdési módokat használja (problémaelemzés, kognitív átstrukturálás, alkalmazkodás), kevésbé hajlamos az érzelmi indíttatású cselekvésre. Hajlamosabb segítséget kérni a környezetétól, mint az éretlen karakter.

A vizsgálataink azt mutatják, hogy a fóiskolai hallgatók körében a borderline temperamentumtípus $69,5 \%$-os, az obszesszív-kompulzív 51\%os mértékben veszélyeztetett arra, hogy az adott temperamentumtípusra jellemző személyiségzavar megjelenjen náluk. A legkevésbé veszélyeztetett ebból a szempontból a ciklotím (3\%) és hisztrionikus $(12,5 \%)$ temperamentumtípus volt.

Vizsgálataink eredményei csak az egyetemi, fóiskolai populációra érvényesek. A vizsgálatok eredményei felvetik annak a szükségességét, hogy a kutatásokat normatív mintán megismételve annak érvényességi határait kiterjesszék.

\section{Irodalom}

Beck, A. T., Beck, R. W. (1972): Screening depressed patients in family practice. A rapid technique. Postgrad Med., 52: 81-85.

Cloninger, C. R. (1987): A systematic method for clinical description and classification of personality variants. Arch. Gen. Psychiatry, 44: 573-588.

Kopp M. (1994): Orvosi pszichológia. SOTE Magatartástudományi Intézet, Budapest. 
Margitics F. (2005): A prediszponáló tényezők kapcsolata szubklinikus depressziós tünetegyüttessel fóiskolai hallgatóknál. Psychiatria Hungarica, 20: 211-223.

Osváth A. (2003): A személyiség pszichobiológiai modelljének és Cloninger Temperamentum és Karakter Kérdóívének (TCI) bemutatása. In: Kállai J., Kézdi B. (szerk.): Új távlatok a klinikai pszichológiában. Új Mandátum Könyvkiadó, Budapest, 161-180.

Rózsa S., Kállai J., Osváth A., Bánki M. Cs. (2005): Temperamentum és karakter: Cloninger pszichobiológiai modellje. A Cloninger-féle temperamentum és karakter kérdőív felhasználói kézikönyve. Medicina Könyvkiadó, Budapest.

Szádóczky E. (lekt.) (2001): Depresszió, szorongás pontozó skálák. EGIS, Budapest.

\section{MARGITICS, FERENC - PAUWLIK, ZSUZSA - PETRIKA, ERZSÉBET \\ INTERRELATIONS OF TEMPERAMENT AND CHARACTER TYPES WITH SUBCLINICAL DEPRESSIVE SYNDROMES, DYSFUNCTIONAL ATTITUDES AND COPING STRATEGIES}

Objectives: The objective of this study is to scrutinize the interrelations of the temperament and character types that are separable well by means of the Cloninger's Temperament and Character Inventory (TCI) with the depressive syndromes, dysfunctional attitudes and coping strategies among college students. Methods: There were 465 female and 216 male students $(n=681)$ involved in the research. The Temperament and Character Inventory was used for separating the temperament and character types while the abridged version of Beck's Depression Scale was applied for measuring the rate of depression. The dysfunctional attitudes were determined by the usage of the Hungarian version of Weismann's Dysfunctional Attitude Scale, and the coping strategies were examined through the Hungarian adaptation of Folkman and Lazarus's Conflict Solving Questionnaire. Results: The findings of the studies demonstrated that each temperament and character type could be typified with an individual combination of depressive syndroms, dysfunctional attitudes, and coping strategies. During our surveys we discovered the dysfunctional attitudes and coping strategies being typical of the mature and immature character types. Conclusions: The results of our studies may provide assistance for the work of experts dealing with the mental health of the increasing number of university and college students, and these findings may be utilised efficiently, primarily in counselling practices and processes.

Keywords: temperament and character types, mature and immature characters, depressive syndromes, dysfunctional attitudes, coping strategies 